\title{
PENGARUH MEDIA GAME KOMPUTER TERHADAP PEMBELAJARAN KOSAKATA BAHASA INGGRIS PADA ANAK REMAJA
}

\author{
Johanes M.G.P. Pramono \\ Christian Ranuntu \\ Leika Kalangi \\ Program Studi Pascasarjana Linguistik \\ Universitas Sam Ratulangi Manado \\ gilangpramono88@gmail.com
}

\begin{abstract}
The purpose of this reaserch is to find out English vocabulary learning process from youth when they play computer game. The method of this research is descriptive qualitative methodwhich collecting data throgh process observe and semi-structured interview. The result of this research is some English vocabulary learning process occur from elements of multimedia inside game such as picture, sound, and animation. The conclusion of this research is English vocabulary learning process from media computer game occur based from motivation of completing mission in the game so that vocabulary learning process occur in pleasing atmosphere.
\end{abstract}

Keywords: Learning, Vocabulary, English, Media, Game, Komputer

\section{PENDAHULUAN}

Sejalan dengan ilmu pengetahuan dan teknologi, kecanggihan alat-alat pendukung kesenangan manusia seperti contoh permainan atau gamedari hasil perkembangan teknologi berupa videogame. Permainan ini dimainkan oleh banyak kalangan seperti remaja, dewasa, dan orang tua.

Videogame yang tujuannya untuk memberikan kesenangan sering kali dicap sebagai hal yang merugikan bagi hampir kebanyakan orangtua di seluruh dunia, tidak terkecuali di Indonesia. Ini disebabkan persoalan dampak negatif yang bagi anak terutama anak sekolah. Permainan dapat menyebabkan kecanduan bermain, obesitas, kerusakan pada indra penglihatan, dan juga menyebabkan anak lupa untuk belajar atau mengerjakan tugas sekolah.

Akan tetapi, bagaimana jika melalui bermain game, mereka bisa belajar, berinteraksi dengan pikiran mereka, dan mungkin berdampak baik bagi proses belajar mereka.Dalam banyak permainan game pasti berkaitan dengan bahasa, dan muncul dialog atau percakapan dan juga perintah dan opsi untuk membantu si pemain game dalam interaksinya dengan permainan tersebut atau untuk menyelesaikan misi tertentu. Bahasa 
yang digunakan adalah bahasa Inggris.

Suardi (dalam Sardiman, 1992:15) lebih lanjut menjelaskan beberapa ciri interaksi dalam pembelajaran yaitu, (1) Ada suatu prosedur (jalannya interaksi) yang direncanakan, didesain untuk mencapai tujuan yang telah ditetapkan, (2) Interaksi pembelajaran membutuhkan disiplin. Disiplin dalam interaksi pembelajaran diartikan sebagai suatu pola perilaku sedemikian rupa menurut ketentuan yang sudah ditaati secara sadar. Dengan melihat ciri tersebut, jelas bahwa game memiliki hampir keseluruhan ciri tersebut, dan yang membedakan disini, game mempunyai keterbatasan dalam materi karena tidak semua materi dapat dibuatkan gamedisebabkan keterbatasan baik perangkat keras maupun perangkat lunak.

Komputer sebagian besar menggunakan bahasa Inggris sebagai bahasa pengantar, sebagai contoh dalam gameAssassin Creed: Brotherhood, dialog yang merupakan perintah misi: You must pass the enemies in stealth mode, do not make noises. "Anda harus melewati musuh-musuh dengan diam-diam dan tidak membuat kegaduhan”. Hal seperti ini banyak ditemui ketika bermain game dan sangat membutuhkan pengetahuan bahasa Inggris untuk mengetahui maksud dari dialog yang ada dalam game. Dengan tuntutan harus menyelesaikan misi dan mengetahui maksud dari misi, maka dengan kecenderungan ini, remaja pasti mencari maksud perintah misi tersebut dan secara tidak langsung, mereka mendapatkan pengetahuan bahasa Inggris.

Kemp dan Dayton (1985) berpendapat bahwa media game dimasukkan ke dalam manfaat media pembelajaran. Media game terdiri dari unsur visual (dapat dilihat), audio (dapat didengar) dan gerak (dapat berinteraksi). Jadi media game ini dapat membangkitkan keingintahuan pemain, merangsang reaksi mereka, memungkinkan pemain menyentuh objek kajian pelajaran, membantu mereka mengkonkretkan sesuatu yang abstrak dan sebagainya.

Dunia gamedalam komputer membuka kemungkinan untuk memperkaya kosakata bagi pembelajar khususnya anak remaja. Game komputer memberikan kesempatan pada pembelajar untuk membaca dan memahami bahasa Inggris dengan suasana yang menyenangkan. Thornbury (2002) menyatakan bahwa faktor kesenangan dapat membantu pembelajar mengingat kata lebih mudah dan adanya unsur kompetisi dalam permainan dapat menggerakkan pembelajar untuk berpartisipasi. Dengan demikian, kosakata bisa diperkaya dengan melakukan hal yang menyenangkan dan tidak membosankan. 


\section{Pengertian Game}

Gameatau permainan adalah sesuatu yang dapat dimainkan dengan aturantertentu sehingga ada yang menang dan ada yang kalah, biasanya dalam kontekstidak serius atau dengan tujuan kesenangan. Permainan merupakan kesibukan yangdipilih sendiri oleh pemain tanpa adanya unsur paksaan, tanpa didesak oleh rasa tanggung jawab dan tidak mempunyai tujuan tertentu. Sedangkan game komputer adalah sebuah program software(perangkat halus) dimana satu atau lebih pemain berusaha untuk membuat keputusan lewat kontrol terhadap objek dan sumber guna memenuhi satu tujuan tertentu.

\section{Pembelajaran Kosakata}

Pembelajaran kosakata harus dikaitkan dengan fungsi bahasa sebagai alat komunikasi. Kosakata hendaknya tidak dipandang sebagai daftar panjang kata-kata yang harus didefinisikan dan dihafalkan. Sebaliknya, kosakata hendaknya dilihat peran pentingnya dalam penggunaan bahasa secara kontekstual dan bermakna. Brown (2001, 377-378) memberikan rambu-rambu pengajaran kosakata yang komunikatif sebagai berikut:

1. Ada waktu khusus untuk pembelajaran kosakata.

2. Siswa belajar kosakata dalam konteks.

3. Penggunaan kamus monolingual ditingkatkan.

4. Siswa didorong untuk mengembangkan strategi untuk menebak makna kata.

5. Pembelajaran kosakata yang tidak terencana dapat terjadi.

\section{Multimedia}

Menurut Barker \& Tucker, dalam Soenarto, (2005: 116), multimedia diartikan sebagai kumpulan dari berbagai peralatan media berbeda yang digunakan untuk presentasi. Dalam pengertian ini multimedia diartikan sebagai ragam media yang digunakan untuk penyajian materi pelajaran, misalnya penggunaanwall chart atau grafik yang dibuat di atas kertas karton yang ditempelkan di dinding.Tan Seng Chee \& Wong (2003: 217) menyatakan bahwa multimediasecara tradisional merujuk kepada penggunaan beberapa media, sedangkanmultimedia pada zaman sekarang merujuk kepada penggunaan gabungan beberapamedia dalam penyajian pembelajaran melalui komputer. Multimedia adalah media 
yang menggabungkan dua unsur atau lebih media yang terdiri dari teks, grafis, gambar, foto, audio, video dan animasi secara terintegrasi.

\section{Pembelajaran KosakataMenggunakan Media}

Menurut Wood (2001: 15), penggunaan multimedia pembelajaran berpotensi meningkatkan pembelajaran kosakata. Dalam multimedia pembelajaran dapat disajikan bentuk permainan, hyperlink, hypertext, dan animasi. Bentuk permainan dapat memberi stimulasi eksternal dan menampilkan berbagai bentuk grafik. Bentuk hyperlink memberi kesempatan kepada pembelajar untuk memperoleh kata-kata baru dalam berbagai konteks melalui akses yang cepat ke teks dan grafik yang diinginkan pembelajar. Bentuk hypertext memungkinkan pembelajar mengklik kata-kata yang diinginkan untuk mendengar pengucapannya dan meningkatkan pemahaman terhadap kata-kata baru yang dipelajari. Sementara itu, animasi dapat meningkatkan pembelajaran kosakata apabila digabungkan dengan narasi yang informatif dan menarik. Sedangakan pada pendapat Nation (2001: 109) menyatakan bahwa "pembelajaran kosakata dengan multimedia berpusat pada kondisi noticing, retrieval, dan generative use. (1) Noticing yaitu bentuk pembelajaran dengan menggunakan tulisan yang diberi warna, disorot, dan diberi cahaya; (2) Retrieval yaitu pembelajaran yang dilakukan dengan penundaan atau pemunculan petunjuk secara berangsur-angsur; (3) Generative use yaitu pembelajaran yang dilakukan dengan melengkapi kosakata dalam berbagai konteks dan bentuk seperti gambar, tulisan, dan suara".Dapat disimpulkan bahwa media pembelajaran dapat berupa alat ataupun kejadian yang mendukung pembelajar dalam menerima pengetahuan. Semua media yang digunakan dapat bertujuan untuk mewujudkan tujuan pembelajaran. Media menjadi alat bantu dalam kegiatan belajar. Dalam hal ini komputer menjadi sarana membantu belajar remaja. Meskipun tidak formal tetapi fungsi dari komputer dalam wujud game mampu mendukung pembelajaran khususnya kosakata.

\section{METODE PENELITIAN}

\section{Pendekatan Penelitian}

Metode yang digunakan dalam penelitian ini adalah metode deskriptif dan kualitatif. Pendekatan kualitatif adalah suatu proses penelitian dan pemahaman yang berdasarkan pada metodologi yang menyelidiki suatu fenomena sosial dan masalah manusia. Pada pendekatan ini, peneliti membuat suatu gambaran kompleks, meneliti kata- 
kata, laporan terinci dari pandangan responden, dan melakukan studi pada situasi yang alami (Creswell, 1998:15).

\section{Sumber Data}

Penelitian ini mengambilresponden 10 anak remaja dengan kriteria responden pada penelitian ini remaja yang bermain dengan rata-rata umur 13-15 tahun atau yang duduk di bangku SMP. Responden harus memiliki jam bermain sekitar 1-2 jam per hari atau 7-14 jam per minggu, itu dikategorikan pemain yang berpegalaman atau sering bermain game.

\section{Teknik Pengumpulan Data}

\section{a. Observasi}

Adapun pedoman observasi untuk mendapatkan data tentang interaksi responden dengan media game adalah sebagai berikut:

a) Mengamati Interaksi remaja dengan game

b) Mengamati animasi, suara, teks, dan gambar pada game.

c) Mengamati pemunculan teks-teks bahasa Inggris.

d) Melihat pemahaman pemain terhadap pemunculan teks-teks bahasa Inggris yang muncul.

\section{b. Wawancara}

Setelah diobservasi selama kurang lebih 1-2 jam, langkah selanjutnya dengan wawancara.

\section{c. Instrumen Penelitian}

Instrumen penelitian yang digunakan dalam penelitian ini adalah daftar pertanyaan dalam wawancara (semi-structured), alat perekam dan kamera digital.

\section{d. Teknik Analisis Data}

Teknik analisis data yang digunakan dalam penelitian ini adalah menggunakan langkah-langkah seperti yang dikemukakan oleh Bungin (dalam Moleong. 2001), yaitu sebagai berikut:

\section{Reduksi Data (Data Reduction)}

Reduksi data, diartikan sebagai proses pemilihan, pemusatan perhatianpada penyederhanaan dan transformasi data yang muncul di lapangan. Reduksi dilakukan sejak pengumpulan datadimulai dengan membuat ringkasan, menulis memo dan sebagainya dengan maksud menyisihkan data/informasi yang tidak relevan.

2. Display Data 
Display data adalah pendeskripsian sekumpulan informasi tersusunyang memberikan kemungkinan adanya penarikan kesimpulan danpengambilan tindakan. Penyajian data kualitatif disajikan dalam bentuk teks naratif. Penyajian data juga dilakukan dengan gambar.

3. Verifikasi dan Penegasan Kesimpulan (Conclution Drawing and Verification)

Merupakan kegiatan akhir dari analisis data. Penarikan kesimpulanberupa kegiatan interpretasi, yaitu menemukan data yang ingin disajikan.

\section{PEMBAHASAN}

\section{Hasil Penelitian}

Penelitian dilaksanakan pada bulan Oktober. Setelah mengamati dan melewati proses wawancara, pembelajaran kosakata bahasa Inggris pada anak remaja melalui media game komputer terdapat pada proses interaksi. Anak remaja berinteraksi dengan teks bahasa Inggris dari beberapa proses interaksi yaitu; (1) Interaksi dari membaca instruksi petunjuk dari game, (2) Interaksi dari memahami dialog yang muncul dari film dalam game, dan (3) Interaksi dari memahami informasi-informasi di dalam game. Melalui proses interaksi tersebut anak remaja yang bermain game mengalami proses pembelajaran.

Proses interaksi yang menimbulkan pembelajaran kosakata bahasa Inggris pada anak remaja, peneliti merangkum hasil pengamatan beberapa proses interaksi muncul pada beberapa judul game yang terdata oleh para anak remaja melalui tabel berkut:

Tabel 2. Judul-judul game yang berpotensi menimbulkan pembelajaran

\begin{tabular}{|c|c|c|c|c|}
\hline \multirow[t]{2}{*}{$\mathrm{NO}$} & \multirow[t]{2}{*}{ Judul Game } & \multicolumn{3}{|c|}{$\begin{array}{l}\text { Proses Interaksi yang menimbulkan pembelajaran } \\
\text { kosakata }\end{array}$} \\
\hline & & $\begin{array}{l}\text { Membaca } \\
\text { instruksi }\end{array}$ & $\begin{array}{l}\text { Memahami } \\
\text { dialog }\end{array}$ & $\begin{array}{l}\text { Memahami } \\
\text { Informasi }\end{array}$ \\
\hline 1 & Metal gear solid: Revenance & $S$ & 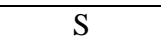 & $S$ \\
\hline 2 & Assassin creed: black flag & $S$ & $S$ & $\mathrm{~S}$ \\
\hline 3 & $\begin{array}{c}\text { Naruto Shippuden: Ultimate ninja storm } 3 \text { full } \\
\text { burst }\end{array}$ & $S$ & $\mathrm{~J}$ & $\mathrm{~T}$ \\
\hline 4 & Fifa 14 & $\mathrm{~S}$ & $\mathrm{~T}$ & $\mathrm{~J}$ \\
\hline 5 & Pro evolution soccer (PES) 2013 & $S$ & $\mathrm{~T}$ & $\mathrm{~J}$ \\
\hline 6 & Last Remnant & $S$ & $S$ & $S$ \\
\hline 7 & Grand thief auto (GTA): San Andreas & S & $S$ & $S$ \\
\hline
\end{tabular}


Keterangan:

(S) : : Sering

(J) : Jarang

(T) : Tidak perlu

Tabel ini merupakan hasil dari observasi dan wawancara untuk mengetahui interaksi dari beberapa game yang menimbulkan proses pembelajaran dengan didasari oleh pedoman observasi. Pada kategori "sering", semua judul game mempunyai instruksi, dialog, dan informasi yang menimbulkan pembelajaran kosakata, dan pemain berusaha memahami akan teks bahasa Inggris yang terdapat di layar komputer termasuk adanya pengaruh dari video, gambar, dan suara.

Selain itu, beberapa judul game lain yang dikategorikan "jarang” karena ditemukan sedikit menimbulkan kemungkinan untuk proses pembelajaran dikarenakan tidak memerlukan pemahaman akan dialog ataupun informasi yang muncul. Pada kategori "tidak perlu", sesuai dengan hasil wawancara, responden tidak mengalami proses interaksi pembelajaran karena tidak membaca tulisan yang tertera karena merasa sudah hafal arti dan maksudnya.

Kemampuan bahasa Inggris menjadi suatu tuntutan mutlak bagi pemain dalam game komputer, tak hanya mencari kesenangan bermain saja tapi seperti dibahas sebelumnya bahwa hampir semua game mempunyai tujuan berbentuk misi untuk diselesaikan. Interaksi dengan bahasa didalam game menjadi keharusan pemain untuk mencapai sesuatu pada game. Dari hasil wawancara, peneliti mengkaitkan penelitian sebelumnya tentang strategistrategi yang muncul ketika pembelajaran kosakata bahasa Inggris terjadi. Strategi-strategi ini dipakai tanpa disadari oleh remaja merupakan proses pembelajaran yang sesuai dengan pendapat dari Bytheway (2011). Penjelasan tentang strategi-strategi tersebut adalah sebagai berikut:

\section{Melihat arti di kamus atau browsing di google terjemahan.}

Dampak pembelajaran bahasa Inggris pada remaja timbul karena adanya tujuan yang harus diselesaikan seperti misi dalam game, sehingga menimbulkan motivasi untuk memahami makna yang dari tulisan yang muncul berupa bahasa Inggris yang mereka tidak pahami secara keseluruhan. Dari hasil wawancara, strategi pertama yang mereka gunakan mencari arti dari teks di kamus. Para pemain mencari kata-kata yang sukar yang berhubungan dengan misi, informasi, dan instruksi yang muncul. Para remaja menyelusuri 
arti dari kosakata yang sukar di handphone dengan menggunakan sarana internet pada handphone atau komputer untuk mengakses google terjemahan.

\section{Meminta bantuan kepada teman.}

Bertanya kepada teman sering menjadi strategi yang digunakan para pemain ketika tidak mengetahui maksud dari teks bahasa Inggris yang muncul. Seperti yang dilaporkan dalam wawancara, strategi meminta bantuan kepada teman yaitu meminta tolong kepada teman terdekat cara menyelesaikan misi yang sukar. Teman akan menjelaskan maksud dari misi, atau juga cara menyelesaikan game. Proses pembelajaran terjadi ketika teman yang menolong menjadi tutor dengan menjelaskan arti dari kosakata-kosakata yang ada di misi sekaligus cara dan teknik menamatkan misi.

\section{Menebak dari konteks.}

Pada hasil wawancara, jika strategi pertama dan kedua tidak tersedia, para pemain menggunakan strategi menebak maksud dari konteks game. Seperti yang dilaporkan oleh Jurgen dan Aldi dalam mereka menebak konteks makna dari game dengan memilih opsi dalam teks tertulis di dalam game.

\section{Pembahasan}

Anak remaja mengalami pembelajaran kosakata Bahasa Inggris melalui media karena pembelajaran kosakata dipengaruhi adanya elemen-elemen multimedia sebagai media pembelajaran yang menjadi pemicu kepada anak remaja untuk belajar kosakata bahasa Inggris dalam game , sesuai dengan apa yang diungkapkan oleh Wood (2001: 15) bahwa:

Penggunaan multimedia pembelajaran berpotensi meningkatkan pembelajaran kosakata. Dalam multimedia pembelajaran dapat disajikan dalam bentuk permainan, hyperlink, hypertext, dan animasi. Permainan dalam game komputermenjadi media pembelajaran kosakata bagi anak remaja dikarenakan adanya penyajian elemen-elemen yang ada pada multimedia.

Selanjutnya, pembelajaran multimedia lewat game komputer disampaikan oleh Nation (2001: 109) yang menyatakan bahwa pembelajaran kosakata dengan multimedia berpusat pada beberapa kondisi seperti noticing, retrieval, dan generative use.Kondisi pembelajaran yang memungkinkan pembelajar mengalami proses pembelajaran dengan menggunakan tulisan yang diberi warna, disorot, dan diberi cahaya. Pada pembelajaran anak remaja dengan media game komputer, kondisi noticing terjadi pada elemen media 
seperti animasi, teks, dan video. Animasi 3D (tiga dimensi) serta film dan dialog mempermudah proses pembelajaran kosakata serta pemahaman akan konteks kalimat.Retrievalyaitu pembelajaran yang dilakukan dengan pemunculan petunjuk secara berangsur-angsur seperti pada interaksi dengan informasi-informasi teks di dalam game. Dan, generative use yaitu pembelajaran yang dilakukan dengan melengkapi kosakata dalam berbagai konteks dan bentuk seperti gambar, tulisan, dan suara.

\section{Kondisi Pembelajaran Kosakata Bahasa Inggrisdari Media Game Komputer}

Penegasan pembelajaran multimedia lewat game komputer disampaikan oleh Nation (2001: 109) yang menyatakan bahwa pembelajaran kosakata dengan multimedia berpusat pada beberapa kondisi seperti noticing, retrieval, dan generative use. Hasil pembahasannya dideskripsikan sebagai berikut:

\section{a. Noticing}

Noticing yaitu bentuk pembelajaran dengan menggunakan tulisan yang diberi warna, disorot, dan diberi cahaya. Pada pembelajaran anak remaja dengan media game komputer, kondisi noticing terjadi pada elemen media seperti animasi, teks, dan video. Animasi 3D (tiga dimensi) serta film dan dialog mempermudah proses pembelajaran kosakata serta pemahaman akan konteks kalimat.

\section{b. Retrieval}

Retrieval yaitu pembelajaran yang dilakukan dengan pemunculan petunjuk secara berangsur-angsur. Media game komputer menyuguhkan banyak informasi dan instruksi yang harus dipahami oleh remaja sebagai pemain. Peneliti mendapati informasi dan instruksi ini selalu muncul secara terus menerus. Didalam komprehensi anak remaja, proses mengenali (recognise) dan memanggil ulang (recall) kata-kata yang dilihat, diingat, dan dikenali (Hatch \& Brown, 1995).

\section{c. Generative use}

Generative use yaitu pembelajaran yang dilakukan dengan melengkapi kosakata dalam berbagai konteks dan bentuk seperti gambar, tulisan, dan suara. Game merupakan kombinasi dari media teks, grafik maupun suara didalam game elemen-elemen tersebut untuk menimbulkan pembelajaran bagi pemain untuk memahami kosakata dan tanpa disadari proses pembelajaran terjadi dari media game komputer ke remaja. 
Adapun faktor-faktor menjadi pemicu terjadinya pembelajaran kosakata padaremaja yang sejalan dengan pendapat Brown (2001) tentang rambu-rambu pengajaran kosakata yang komunikatif yaitu sebagai berikut:

a. Terdapat media gambar, suara, dan teks yang mampu mempermudah remaja dalam mengingat kosakata.

b. Adanya pengulangan materidengan tujuan untuk lebih mengingatkan remaja pada kosakata yang telah dipahami.

c. Adanya motivasi yang dari remaja untuk mencapai sesuatu didalam game yang menciptakan proses pembelajaran.

d. Adanya ketertarikan bagi remaja untuk belajar bahasa Inggrisuntuk berhadapan dengan situasi didalam game.

\section{KESIMPULAN}

Berdasarkan hasil penelitian pada pembelajaran kosakata bahasa Inggris lewat media game komputer pada anak remaja dapat ditarik kesimpulan sebagai berikut:

a. Para remaja yang bermain game mengalami proses belajar bahasa Inggris karena adanya interaksi dengan media game komputer. Proses pembelajaran yang terjadi karena adanya motivasi untuk menyelesaikan misi dalam game. Motivasi ini didasari kesenangan menimbulkan efektifitas pembelajaran.

b. Elemen dalam media seperti animasi, video, teks, dan suara yang ada pada game komputer menjadi tutor, stimulator, dan motivator kepada para remaja yang menimbulkan proses pembelajaran lewat kosakata bahasa Inggris sebagai awal pemahaman mengerti akan makna dalam keseluruhan teks bahasa Inggris. Interaksiinteraksi para remaja dengan game seperti memahami dialog, membaca instruksi dan informasi menjadi alasan kuat munculnya motivasi untuk belajar. Dari interaksiinteraksi tersebut menciptakan strategi pembelajaran bahasa dengan cara mencari makna di kamus, bertanya pada teman, dan menebak dari konteks kalimat pada teks.

Berdasarkan kesimpulan di atas, maka peneliti menyarankan beberapa hal sebagai berikut.

a) Dengan menjamurnya game komputer di seluruh dunia, para peneliti dan praktisi pendidikan harus segera mengambil langkah positif dengan mengambil nilai edukatif 
dalam semua jenis permainan komputer. Tujuannya agar belajar menjadi fun (menyenangkan), dan bermain game juga mengandung nilai-nilai edukatif.

b) Sebagai orangtua atau pendidik, kita menyadari dampak negatif dari game komputer yang dapat merusak akhlak anak, membuat kecanduan bermain, melupakan belajar atau mengerjakan tugas sekolah, berperilaku menyimpang dari batas moral dan agama, bertingkah laku "aneh" karena meniru pengalaman dari game, dan sebagainya. Akan tetapi, di sisi lain, permainan komputer, termasuk game online, mengandung potensi yang dapat membelajarkan anak tentang kosakata Bahasa karena adanya motivasi untuk pembelajaran. Solusi yang baik jika para orang tua dan pendidik mensosialisasikan dampak negatif dari game dan memberikan batasan-batasan dalam bermain game.

\section{DAFTAR PUSTAKA}

Abu Bakar Sulaiman., A. Gani. \& Syafri K. (1986). Kosa kata bahasa Melayu Riau.Jakarta: Pusat Pembinaan dan Pengembangan Bahasa Departemen Pendidikandan Kebudayaan.

Ahmadi, H. Abu dan Supriyono Widodo. (2004). Psikologi Belajar. Jakarta:Rineka Cipta Aminuddin.(1994).Semantik: Pengantar Studi Tentang Makna. Bandung: Sinar Baru.

Basiran, Mokh.(1999)Apakah yang Dituntut GBPP Bahasa Indonesia Kurikulum 1994? Yogyakarta: Depdikbud.

Bytheway, J. (2011) Vocabulary learning strategies in massively multiplayer online roleplaying games: a thesis submitted to the Victoria University of Wellington in partial fulfilment of the requirements for the degree. Unpublished Masters Thesis.

Brown. (2000). Principle of Language Learning and Teaching. New Yersey: Prentice Hall,.

Cresswell, J.W.(1998)Research Design:Qualitative \& Quantitative Approaches. London: SAGE Publicational.

Degeng, I.N.S.(1997)Strategi Pembelajaran Mengorganisasi Isi dengan Model Elaborasi. Malang: IKIP dan IPTDI.

Depdikbud.(1995)Pedoman Proses Belajar Mengajar di SD. Jakarta: Proyek Pembinaan Sekolah Dasar.

Gee, J. P. (2007) What Video Games Have to Teach Us About Learning and Literacy. Second Edition: Revised and Updated Edition (2nd ed.). New York: Palgrave Macmillan.

Gilbert, D. (2002). Multimedia Technology, Queensland: University of Queensland

Hatch, E. \& Brown, C. (1995). Vocabulary, Semantics, and Language Education. Cambridge: Cambridge University Press

Husserl, E. (1931). Ideas: General Introduction to Pure Phenomenology. London: George Allan \& Unwin

Hoskisson, K. \& Tompkins, G. E. (1987) Language arts: Content and teaching strategies. Melbourne: Merill Publishing Company.

Moleong, Lexi J. (2001). Metologi Penelitian Kualitatif. Bandung: Remaja Rosydakarya. 
Kemp, J.E. \& Dayton D.K. 1985. Planning and Producing Instructional Media. Cambridge: Harper \& Row Publisher.

Nazir, Moh. (2005). Metode Penelitian. Cetakan Pertama. Penerbit Ghalia Indonesia: Jakarta.

Nation, I. S. P. (2001). Learning vocabulary in another language. Cambridge: Cambridge University Press.

(2005). Teaching Vocabulary. Asian EFL Journal. Volume 7. Issue 3. September 2005. http://www.asian-efljournal.com/September_05_pn.php

Nunan, D. (1991). Language teaching methodology: A textbook for teachers. Sydney:Prentice Hall International (UK) Ltd.

Pateda, Mansoer dan Pulubuhu, Jeni.(2011)Linguistik Terapan. Gorontalo: Viladan,.

Rama, Paul., Black, Rebecca., Van Es, E., \& Warschauer, M. (2012) . Affordance for second language learning in WoW. California: European Association for Computer Assisted Language Learning

Robert L. G. dan William R. M.(1975)Current Strategies for Teachers. California: Goodyear Publishing Company,

Rosman, Fuziah, \&Alias, Norlidah, \&Siraj Saedah, Kenayathullah BanuHusaina,\&Zakaria Razak Abd \& Darusalam Ghazali (2013). Potential of Video Games in Learning Bahasa Among International University Students in Malaysia. The Turkish Online Journal of Educational Technology - October 2013, volume 12 issue 4.

Sardiman, A.M. 1992. Interaksi dan Motivasi Belajar Mengajar. Jakarta: Gunung Agung

Sugiyono. (2010). Metode Penelitian Pendidikan, Pendekatan Kuantitatif, Kualitatif, dan R\&D. Bandung: Alfabeta.

Suharsimi, Arikunto. (2009). Dasar-Dasar Evaluasi Pendidikan. Jakarta: Bumi Aksara.

Suharsimi, Arikunto. (2010). Prosedur Penelitian Suatu Pendekatan Praktik. Jakarta: PT. Rineka Cipta.

Sunaryo Soenarto. (2005). Pengembangan multimedia pembelajaran interaktif matakuliah tata hidang. Inotek: Jurnal inovasi dan aplikasi teknologi.Volume 9,Nomor 1, Februari 2005.

Shepherd, J. J., Doe, R. J., Arnold, M., Cheek, N., Zhu, Y. \& Tang, J. (2011). Lost in the Middle Kingdom: a second language acquisition videogame. In Proceedings of the 49th Annual Southeast Regional Conference (ACM-SE '11). ACM, New York, NY, USA, 290-294. DOI=10.1145/2016039.2016114 http://doi.acm.org/10.1145/2016039.2016114

Suyanto, (2004). Analisis dan Desain Aplikasi Multimedia untuk Pemasaran, Andi Offset Yogyakarta.

Syaifuddin, Azwar. 2001. Reabilitas dan Validitas. Yogyakarta: Pustaka Belajar Offset. (hal.5)

Sykes, J., Oskoz, A. and Thorne, S. L. (2008) Web 2.0, Synthetic Immersive Environments, and the Future of Language Education. CALICO Journal, 25(3): 528-546.

Tan Seng Chee \& Angela F. L. Wong (Eds.) (2003). Teaching and learning with technology: An asia-pacific perspective. Singapore: Prentice Hall

Thornbury, S. 2002. How to Teach Vocabulary. Essex: Pearson Education Limited

Thorne, S. L. (2008) Transcultural communication in open Internet environments and massively multiplayer online games. In: Magnan, S. (ed.), Mediating Discourse Online. Amsterdam: John Benjamins, 305-327. 
Thorne, S. L., Black, R. and Sykes, J. (2009) Second Language Use, Socialization, and Learning in Internet Interest Communities and Online Games. Modern Language Journal, 93: 802-821.

Thorne, S. L. (2010) The "intercultural turn" and language learning in the crucible of new media. Telecollaboration, 2: 139-164.

Wood, J. (2001). Can software support children's vocabulary development? [versi elektronik]. Journal of Language Learning \& Technology, 5, 166-265.

Definisi game. 2014. http://syhabbers.blogspot.com/2011/05/definisi-game-dan-jenisjenisnya.html diakses Juli 2014

2014. http://chikhungunya.wordpress.com/2011/05/26/definisi-game-danjenis-jenisnya/ diakses Juli 2014 2014.www.Oxfordonlinedictionaries.com/definition/English/game/. diakses September 2014 